\title{
Principles of administrative judiciary in Ukraine
}

Principios del poder judicial administrativo en Ucrania

\author{
Princípios do judiciário administrativo na Ucrânia
}

\author{
Yevhen Leheza ${ }^{1}$ \\ Oleksandr Shamara² \\ Viktor Chalavan ${ }^{3}$
}

\begin{abstract}
Received: August $27^{\text {th }}, 2021$
Accepted: October $4^{\text {th }}, 2021$

Published: December $24^{\text {th }}, 2021$

How to cite this article:

Yevhen Leheza, Oleksandr Shamara \& Viktor Chalavan. Principles of administrative judiciary in Ukraine. DIXI, vol. 24, $\mathrm{n}^{\circ}$. 1, enero-junio 2022, 1-11.

DOI: https://doi.org/10.16925/2357-5891.2022.01.08
\end{abstract}

Research article. https://doi.org/10.16925/2357-5891.2022.01.08

1 Doctor of Science in Law. Professor at the Department of Administrative and Customs Law, University of Customs and Finance, Ukraine.

E-mail: yevhenleheza@gmail.com

ORCID: https://orcid.org/0000-0001-9134-8499

2 PhD in Law, Senior Scientific Officer. Professor of the Department of Law, Dniprovsky Humanitarian University Dnipro, Ukraine.

E-mail: alexandr79shamara@gmail.com

3 PhD in History, Professor at the Department of Tactical and Special Disciplines, Academy of State Penitentiary Service, Ukraine.

E-mail: vchal77@ukr.net

ORCID: https://orchid.org/0000-0002-0053-2387 


\section{Abstract}

Purpose: This article is devoted to scientific and theoretical research of modern system of principles for administrative procedural law in updated conditions of the Ukrainian state development, based on the needs of qualitative provision and realization of legal rights, freedoms and interests of natural and legal persons, in the sphere of public and legal relations.

Main content: The author analyzed the administrative law regulations, and the doctrine of administrative procedural law as for determining nature and significance of the basic principles, which define the nature, structure, social orientation, and basic properties of legal regulation of this branch of law, and which on the other side create appropriate organizational and functional conditions for administrative procedural activities.

Methodology: Materials and methods for research were based on the analysis of documentary sources. The basis is the dialectical method of cognition of the facts of social reality, on which the formal legal and comparative legal approaches are largely based.

Conclusions: The principles of administrative procedural law can be divided into those that directly reflect the specifics and content of this branch of law, determine its features, purpose, objectives and intention, as well as administrative procedural principles, i.e., basic principles enshrined in administrative procedural law, which do not undergo significant changes, nor determine the nature and content of the activities of all subjects of administrative procedural legal relations.

Keywords: Administrative legal proceedings, administrative procedural law, administrative procedural norm, administrative process, guidelines, principles of law.

\section{Resumen}

Objetivo: este artículo está dedicado a la investigación científica y teórica del sistema moderno de principios para el derecho procesal administrativo en las condiciones actualizadas del desarrollo del estado ucraniano, basado en las necesidades de la provisión cualitativa y la realización de los derechos legales, las libertades y los intereses de las personas físicas y jurídicas, en la esfera de las relaciones públicas y legales.

Contenido principal: el autor analizó las normas de derecho administrativo, y la doctrina del derecho procesal administrativo en cuanto a la determinación de la naturaleza y el significado de los principios básicos, que definen la naturaleza, la estructura, la orientación social, y las propiedades básicas de la regulación jurídica de esta rama del derecho, y que por otro lado crean condiciones organizativas y funcionales adecuadas para las actividades de procedimiento administrativo.

Metodología: los materiales y métodos de investigación se basaron en el análisis de fuentes documentales. La base es el método dialéctico de conocimiento de los hechos de la realidad social, en el que se basan en gran medida los enfoques jurídicos formales y jurídicos comparados.

Conclusiones: los principios del derecho procesal administrativo pueden dividirse en aquellos que reflejan directamente las especificidades y el contenido de esta rama del derecho, determinan sus características, finalidad, objetivos e intención, así como los principios procesales administrativos, es decir, los principios básicos consagrados en el derecho procesal administrativo, que no sufren cambios significativos, ni determinan la naturaleza y el contenido de las actividades de todos los sujetos de las relaciones jurídicas procesales administrativas.

Palabras clave: procedimiento jurídico administrativo, derecho procesal administrativo, norma procesal administrativa, proceso administrativo, directrices, principios del derecho. 


\section{Resumo}

Objetivo: Este artigo é dedicado à pesquisa científica e teórica do moderno sistema de princípios do direito processual administrativo em condições atualizadas do desenvolvimento do Estado ucraniano, com base nas necessidades de provisão qualitativa e realização dos direitos, liberdades e interesses legais de pessoas físicas e jurídicas, na esfera das relações públicas e jurídicas.

Conteúdo principal: 0 autor analisou os regulamentos de direito administrativo, e a doutrina de direito processual administrativo quanto à determinação da natureza e significado dos princípios básicos, que definem a natureza, estrutura, orientação social e propriedades básicas da regulamentação jurídica deste ramo do direito, e que por outro lado criam condições organizacionais e funcionais apropriadas para as atividades processuais administrativas.

Metodologia: Os materiais e métodos de pesquisa foram baseados na análise de fontes documentais. A base é o método dialético de conhecimento dos fatos da realidade social, no qual as abordagens jurídicas formais e jurídicas comparativas se baseiam em grande parte.

Conclusões: Os princípios do direito processual administrativo podem ser divididos naqueles que refletem diretamente as especificidades e o conteúdo deste ramo do direito, determinam suas características, finalidade, objetivos e intenção, bem como os princípios procedimentais administrativos, ou seja, princípios básicos consagrados no direito processual administrativo, que não sofrem alterações significativas, nem determinam a natureza e o conteúdo das atividades de todos os sujeitos das relações jurídicas procedimentais administrativas.

Palavras-chave: Processos judiciais administrativos, direito processual administrativo, norma processual administrativa, processo administrativo, diretrizes, princípios de direito.

\section{INTRODUCTION}

Global political, economic, social and legal transformations that are taking place in the state against the background of numerous reforms in all spheres of the society, directly affect the entire domestic legal system, and its individual branches and institutions. In the last two decades alone, the current legislation has been significantly updated and supplemented.

An influential codified act was adopted - the Code of Administrative Proceedings of Ukraine (hereinafter referred to as CAPU), which finally completed formation of the national administrative justice institution (although the process of making significant changes and additions to it is still ongoing). More than a hundred amendments were made to the main codified act of administrative torts (the Code of Ukraine on Administrative Offenses); and the dispersion of administrative procedural norms in the legislation in general testifies to their increase not only in number, but also in form of replenishment with fundamentally new concepts and categories. It is obvious that today it is extremely urgent to rethink certain legislative structures and categories 
defined in the norms of administrative and procedural legislation, in particular including such categories as principles.

\section{LITERATURE REVIEW}

The purpose of legal principles in general is difficult to be overestimated. In any case, their function is to ensure ideological unity of lawmaking, law enforcement, as well as law and order in general. Each principle is an idea, i.e., a spontaneous thought as a product of real human thinking, which reflects the most significant understanding of law and legal worldview. Ideas-principles as a general social phenomenon indicate what the law should be. Obviously, in the same way (i.e., as a result of the society evolutionary development), certain concepts and ideas about the legal process, its purpose and objectives, role and place in the society are formed. Such views further form the basis for the formulation of starting points, which over time may represent a "shell" of legal principles.

Turning directly to the study of the principles of administrative procedural law, at the onset we cannot fail to note the fundamental position (expressed by V.S. Bukina), which has not still lost its relevance: "The principles of a certain branch of law reflect fundamentals of its construction, functioning and development". This intermediate conclusion directly refers to administrative procedural law, whose principles permeate all its norms and institutions, reflect the basic provisions, specificity, content and purpose as those of a branch of law, and they also define administrative procedural activity, administrative procedural powers, and administrative procedural status of administrative process subjects, are based on the formation and functioning of administrative procedural legal relations. Moreover, the principles of administrative procedural law should be presented as such fundamental principles enshrined in law, which for a long time do not undergo significant changes and ensure implementation of tasks assigned to this area. A.M. Kolodiy notes that "[...] within the framework of law-making, new legal principles are born with the help of legal practice, and they evolutionarily cancel the effect of old, outdated principles".2

1 Valentina Stepanovna Bukina. PRINCIPLES OF SOVIET CIVIL PROCEDURAL LAW (THEORETICAL ISSUES OF CONCEPT AND SYSTEM). University A.A. Zhdanov. (1975).

2 Anatoliy Mykolayovych Kolodiy. Principles of law: Genesis, concepts, classification and implementation. ALMANAC OF LAW. 2012. 


\section{RESULTS AND DISCUSSION}

It should be noted at once that systematization of scientific approaches, understandings and legal ideas about theoretical interpretations of administrative procedural law, depending on the understanding of the "administrative process" definition in today's conditions, gives an opportunity to define administrative procedural law as one of the independent procedural branches of law. The last is a properly ordered set of administrative-procedural norms (rules) enshrined in administrative procedural legislation governing public relations between the court and participants in court proceedings, in the sphere of administrative proceedings for the purpose to effectively protect rights, freedoms and interests of individuals, rights and interests of legal entities from being violated by subjects of power. It is based on this approach to understand the content of administrative procedural law as an independent branch of law. The fundamental and guiding principles of the latter will be considered in this article.

From the scientific point of view, expediency of studying principles of any branch of procedural law consists in the fact that these branches belong to one of the fundamental categories of the Ukrainian legal science, occupy a priority place in its conceptual apparatus, and act as a kind of a "coordinate system" for scientific analysis of procedural legal relations in the process of their functioning. The law's procedural branches are characterized by a higher degree of generality of normative attributes than in case with the branches of material law. As mentioned on pages of legal literature, research of any branch principles of law should be carried out based on their origin, evolution, legal nature, importance and practical implementation. It is also important to deduce the legal essence from the philosophical understanding of the principles. ${ }^{3}$ It is no coincidence that the pioneers in the studying of problems of principles in legal science have historically been representatives of procedural branches (they belong to the science of criminal procedure, where the doctrine of principles arose much earlier than in other branches of jurisprudence). ${ }^{4}$

The term "principle" as a general scientific category is of Latin origin (Latin "principium") and can be interpreted as: basic, starting point of any theory, doctrine,

3 Angela Alexandrovna Polyanichko. Principles of law: A modern general theoretical view. UNIVERSITY SCIENTIFIC NOTES 47. 2013.

4 Yevhen Leheza, Maryna Savielieva \& Olena Dzhafarova. Structural and legal analysis of scientific activity regulation in developed countries. BALTIC JOURNAL OF ECONOMIC StUdies 3. 2018. Pág. 147-157. Available at: https://doi.org/10.30525/2256-0742 /2018-4-3-147-157 
scientific system ${ }^{5}$; beliefs, norms, rules guiding someone in life and behavior; canon; ${ }^{6}$ the feature underlying the creation or implementation of something, the method of creating or implementing something; beliefs, norms, rules that guide someone in life, behavior, or the basic, starting point of any scientific system, theory, ideological direction, etc.? The terms "basic", "guiding" or "starting", which are used in almost all definitions provided in reference publications, indicate that this system-forming element, given its essence, is endowed with the highest imperative, it encompasses a fundamental rule that does not require any proof.

Theorists of law, who have studied the principles of law, come to the same conclusion that these are "basic ideas or initial provisions that characterize the content of law, patterns of its development, essence and purpose as a special social regulator". ${ }^{8}$ In any case, definition of "principles of law" is used under specific conditions when it comes to a basic rule or requirement that belongs to the sphere of jurisprudence, and is considered in connection with either the law in general or a particular activity. In specific cases, the definition of "principles" can either be interpreted or clarified, depending on the range of its use and functional orientation. ${ }^{9}$

Norms of the CAPU determining the principles of administrative proceedings are worth to be mentioned as an example. The latest version of this coded act clearly demonstrates legislators not only moved the list of basic principles to the beginning of this legislative act, but also placed them together with the provisions on the tasks of administrative proceedings (Part 3 Art. 2 of the CAPU), and supplemented with the following new principles: understanding of the time of court proceedings; inadmissibility of abuse of procedural rights; reimbursement of court costs of individuals and legal entities in whose favor the court decision is made.10

Judicial proceedings in administrative cases are characterized by certain stages, their own goals and objectives, a special range of participants and certain specifics

5 Vladimir Vladimirovich Lopatina \& Lyudmila Evgenievna Lopatina. SMALL EXPLANATORY DICTIONARY OF THE RUSSIAN LANGUAGE. [Unpublished]. (1990). P. 456

6 Vasil Yaremenko \& Oxana Slipushko. NEW EXPLANATORY DICTIONARY OF THE UKRAINIAN LANGUAGE: IN 4 Volumes. Aconite. (1988). Volume 3: Processing.

7 Vasil Yaremenko \& Oxana Slipushko. NEW EXPLANATORY DICTIONARY OF THE UKRAINIAN LANGUAGE: IN 3 VolUMES. Aconite. (2007).

8 Mikhail Markovich Dobkin. LOCAL STATE ADMINISTRATIONS: FORMATION, DEVELOPMENT AND FUNCTIONING. Golden Mile. (2012). P. 567.

9 Olga Fyodorovna Skakun. THEORY OF STATE AND LAW (ENCYCLOPEDIC COURSE). Espada. (2005). P. 537.

10 Yevhen Leheza, Tatiana Filipenko, Olha Sokolenko, Valerii Darahan \& Oleksii Kucherenko. Ensuring human rights in Ukraine: Problematic issues and ways of their solution in the social and legal sphere. CUESTIONES POLítICAS 64. January-June 2020. P. 123-136. Available at: https://doi.org/10.46398/cuestpol.3764.10 
of their procedural status, a set of procedural actions, the amount of legal facts, and legal results and their procedural design. As a result, the principles functioning within a certain institute of administrative procedural law or separate administrative proceeding were thoroughly studied by scientists at the proper level. ${ }^{11}$ It is worth mentioning O.V. Kuzmenko's monograph "Theoretical Principles of the Administrative Process", its author points out that the principles form a structural conglomerate which constitutes the ideological basis of the public administration and its officials in the procedure of meeting public interests. The researcher systematically analyzed the principles of various administrative proceedings and viewed them as administrative and procedural principles. ${ }^{12}$

Since 2005 (with the introduction of the CAPU), and till now, most scientific publications and theses have been devoted to the analysis of separate principles of the administrative judicial process. This state of scientific developments on this issue does not cause any complaints, because until the mid-December 2017 the CAPU clearly defined the concept of "administrative process" (paragraph 5, Part 1 Art. of the Code) as "legal relations formed during implementation of administrative proceedings." That is why the above-mentioned researches were conducted on the basis of the legislative requirement. The researchers equated the principles of administrative process to the principles of administrative proceedings and considered them as the basis, beginning, fundamental, and most abstract rules (basic requirements, principles), which serve as indisputable requirements underlying activities performed by the administrative court to resolve its cases fairly. ${ }^{13}$

According to scientists, these principles are the basic normative-governing provision objectively existing as a category of legal awareness and due to the need to regulate public relations enshrined in procedural law, which forms the borders for execution and development of administrative proceedings. ${ }^{14}$ Such definitions indicate that the procedure for conducting administrative proceedings is provided by a set and system of procedural actions, which are based on the principles reproduced in the principles of administrative procedural legislation, and in particular in the principles the Code of Administrative Proceedings of Ukraine (CAPU). Principles determine the main

11 Elena Anatoliyivna Zadykhayla. ADMINISTRATIVE LAW OF UKRAINE (GENERAL PART). LaW. (2016). P. 298.

12 Oksana Vladimirovna Kuzmenko. THEORETICAL PRINCIPLES OF THE ADMINISTRATIVE PROCESS. Attica. (2005).

13 Valery Konstantinovich Matviychuk. SCIENTIFIC AND PRACTICAL COMMENTARY TO THE CODE OF AdMINISTRATIVE PROCEDURE OF UKRAINe. 2nd edition. Alerta. (2008). Volume 1.

14 Sergiy Antonovych Bondarchuk. PRINCIPLES OF ADMINISTRATIVE JUSTICE OF UKRAINE. Kharkiv National University. (2010). P. 206. 
points in the organization and activity of the administrative court with provisions of a more detailed nature appearing from these main points. That is, legal requirements, rules contained in the principles of administrative proceedings, run as the "starting line" through the entire course of consideration and resolution of administrative cases, they determine contents of the relevant specific procedural rules, as well as procedural activities, carried out on their basis. ${ }^{15}$

Let us point out the characteristic features of this legal phenomenon based on the above observations and conclusions. Such features include:

1. legal orientation - each principle is based on a certain idea, theory, concept or view, which is a prerequisite for its emergence and it is always determined by social, legal, ideological factors and values of social life ;

2. normative and textual fixation - the principles are reflected in the norms of legislation by their textual fixation;

3. universality and effectiveness - principles of administrative procedural law viewed as universally binding and normative provisions determine formation and prospects of development of this branch of law, they are directly related to its norms and institutions, in particular principles have practical and general significance for each of them and determine their basic properties and typical features;

4. stability and stability - the principles must not undergo significant changes for a long time and ensure the implementation of the main goal of this industry, that is, to ensure the proper level of realization and protection of individuals and legal entities of their rights, freedoms and legitimate interests from violations by government powers;

5. firmness and certainty - principles must have a separate clearly defined content, in particular, certain content elements of one principle must not repeat content elements of other principles of administrative procedural law or be derived from them;

6. in case of violation or non-compliance with the principles, during making decision of an administrative case, the court decision shall be subject to cancellation. ${ }^{16}$

15 Yevhen Leheza, Iryna Odyntsova \& Natalia Dmytrenko. Teoría y regulación legal del apoyo informativo de los procedimientos administrativos en Ucrania. RATIO JURIS UNAULA 32. 2021. P. 291-306. Available at: https://doi.org/10.24142/raju.v16n32a12

16 Yevhen Dorokhina, Yuliia Leheza, Oleksandr Shamara, Serhii Miroshnychenko \& Vita Moroz. Citizens' participation in the fight against criminal offences: Political and legal aspects. CUESTIONES POLítICAS 69. 2021. P. 212-224. Available at: https://doi. org/10.46398/cuestpol.3969.12 
An interesting approach is followed by E.F. Demsky. He distinguishes two independent groups (types) of principles, in particular:

1. principles of administrative procedural law (rule of law; presumption of legality of actions and requirements of the subject of appeal and the person concerned; supremacy of law in the system of administrative procedural regulations; ensuring and protecting interests of individuals and the state; differentiation and specialization of the administrative process; compliance of norms of the procedural law of Ukraine with provisions of international legal acts);

2. principles of administrative process, or administrative-procedural principles:

a) functional principles, which determine direction of the administrative process as well as form and content of its institutes;

b) organizational principles that determine procedural activity of bodies authorized to consider administrative cases. This position is justified by the fact that it is a mistake to equate principles of law (which determine functioning of the system) with contents of law and the principles of the subjects of legal relations. Its components, which alongside with the method of procedural actions, guarantees of administrative proceedings and the legal status of the subjects of the administrative process, form the structure of the administrative-procedural regime (procedural form). ${ }^{17}$

The listed individual principles (which are part of each group of proposed fundamentals) have repeatedly been the subject of research. Their content and essence at the appropriate scientific level are set out in scientific publications and monographs.

\section{CONCLUSION}

When viewing the principles of administrative procedural law, we consider it expedient to divide them into those that directly reflect the specifics and content of this branch of law, and determine its features, purpose, objectives and intention, as well as administrative procedural principles, i.e., basic principles enshrined in administrative procedural law which do not undergo significant changes, nor determine the nature

17 Eduard Demsky. Administrative Procedural law of UKRaINE. Attica. (2008). P. 496. 
and content of the activities of all subjects of administrative procedural legal relations. The functional purpose of principles is to ensure a relatively stable vector orientation for settlement of administrative procedural relations arising from the protection of rights, freedoms and interests of individuals, as well as rights and interests of legal entities from being violated by subjects of power during court proceedings in the sphere of public and relations.

\section{REFERENCES}

Anatoliy Mykolayovych Kolodiy. Principles of law: Genesis, concepts, classification and implementation. ALMANAC OF LAW. 2012.

Angela Alexandrovna Polyanichko. Principles of law: A modern general theoretical view. UNIVERSITY SCIENTIFIC NOTES 47. 2013.

Eduard Demsky. Administrative procedural law of Ukraine. Attica. (2008).

Elena Anatoliyivna Zadykhayla. Administrative LAw of UkRAIne (GEnERAL PART). Law. (2016).

Mikhail Markovich Dobkin. Local StATE administrations: Formation, Development and FUNCTIONING. Golden Mile. (2012).

Oksana Vladimirovna Kuzmenko. THeOretiCAL PRINCIPLES OF THE ADMINISTRATIVE PROCESS. Attica. (2005).

Olga Fyodorovna Skakun. THEORY of StATE AND LAW (ENCYCLOPEDIC CourSE). Espada. (2005).

Sergiy Antonovych Bondarchuk. Principles of administrative JUSTICE OF UKRaINE. Kharkiv National University. (2010).

Valentina Stepanovna Bukina. PRINCIPLES OF SOVIET CIVIL PROCEDURAL LAW (THEORETICAL ISSUES OF CONCEPT AND SYSTEM). University A.A. Zhdanov. (1975).

Valery Konstantinovich Matviychuk. SCIENTIFIC AND PRACTICAL COMmENTARY tO THE CODE OF Administrative Procedure of UkRAINe. 2nd edition. Alerta. (2008).

Vasil Yaremenko \& Oxana Slipushko. NEW EXPLANATORY DICTIONARY OF THE UKRAINIAN LANGUAGE: IN 3 Volumes. Aconite. (2007). 
Vasil Yaremenko \& Oxana Slipushko. NeW EXPLANATORY DICTIONARY OF THE UKRAINIAN LANGUAGE: IN 4 VOLUmES. Aconite. (1988).

Vladimir Vladimirovich Lopatina \& Lyudmila Evgenievna Lopatina. SMALL EXPLANATORY DICTIONARY OF THE RUSSIAN LANGUAGE. [Unpublished]. (1990).

Yevhen Dorokhina, Yuliia Leheza, Oleksandr Shamara, Serhii Miroshnychenko \& Vita Moroz. Citizens' participation in the fight against criminal offences: Political and legal aspects. CUESTIONES Políticas 69. 2021. P. 212-224. Available at: https://doi.org/10.46398/cuestpol.3969.12

Yevhen Leheza, Iryna Odyntsova \& Natalia Dmytrenko. Teoría y regulación legal del apoyo informativo de los procedimientos administrativos en Ucrania. RATIO JURIS UNAULA 32. 2021. P. 291-306. Available at: https://doi.org/10.24142/raju.v16n32a12

Yevhen Leheza, Maryna Savielieva \& Olena Dzhafarova. Structural and legal analysis of scientific activity regulation in developed countries. BALTIC JoURNAL OF ECONOMIC STUDIES 3. 2018. Pág. 147-157. Available at: https://doi.org/10.30525/2256-0742/2018-4-3-147-157

Yevhen Leheza, Tatiana Filipenko, Olha Sokolenko, Valerii Darahan \& Oleksii Kucherenko. Ensuring human rights in Ukraine: Problematic issues and ways of their solution in the social and legal sphere. Cuestiones Políticas 64. January-June 2020. P. 123-136. Available at: https://doi. org/10.46398/cuestpol.3764.10 